Metka SITAR

\title{
Nova planerska kultura - iniciativa za varstvo okolja
}

\begin{abstract}
Ċeprav se drugo tisočletje približuje koncu, se vprašanja preživetja človeštva, kako ustvariti zdravo in prijetno okolje, še vedno izmika pravim odgovorom. Vzpodbudna je ugotovitev, da je človek danes $z$ močno osebno angažiranostjo odločen ohraniti naravno ravnovesje za bivanje - še več, celo spremeniti dosedanji način življenja in ga $\mathrm{v}$ zavesti omejenosti naravnih virov prilagoditi danostim razvoja našega planeta.
\end{abstract}

Ta vprašanja, ki so po svojem bistvu vprašanja osebne odgovornosti do okolja, se nanašajo na nas kot posameznike in hkrati kot člane širše skupnosti. Predstavljati bi morala osnovo vseh razmišljanj o načrtovanju prostora, ki po svoji vsebini in vlogi v družbi ščiti ter ohranja kvalitete okolja. S svojimi odločitvami bistveno vpliva na razvoj okolja v želeno smer.

\section{Ali je v današnjih pogojih globalnega sveta planerska stroka še sposobna ohranjati tradicionalno poslanstvo?}

Dogajanja v družbi, ki posredno ali neposredno vplivajo na okolje, so postala kompleksnejša. Zdi se, da sedanjo fazo gospodarskega in družbenega razvoja na mnogih področjih zaznamuje določena nesigurnost, ki jo zaznavamo kot pomanjkanje smiselnih in jasnih konceptov. To velja tudi za planiranje, urbanizem, arhitekturo, skratka za dejavnosti načrtovanja prostora nasploh. Spremembe v družbi, doma in v tujini, evropeizacija Slovenije $z$ vsemi prednostmi in slabostmi, so namreč zlasti $\mathrm{v}$ zadnjem desetletju odločilno spremenile razmere in pogoje profesionalnega dela. Prostor je namreč tisti, ki se prvi odziva na spremembe; nastajajo nove strukture, odnosi v prostoru, znova odkrivamo mesto kot osrednje območje človekovih aktivnosti itd. V teh procesih ni prepoznati kakšnih posebnih planerskih konceptov, ki bi osmislili stalne prostorske spremembe. Prispevek načrtovalcev v kulturnem razvoju družbe se v klasičnem smislu poklicnega poslanstva vedno bolj izgublja in prilagaja deregulacijskim trendom zakonitosti trga kapitala.

Planiranje razumemo danes $\mathrm{v}$ prvi vrsti kot urejanje urbanega prostora, katerega vloga se izrazito spreminja. Osrednje zanimanje je usmerjeno $\mathrm{k}$ osrednjemu urbanemu prostoru - mestu, ki v najnovejšem času izgublja svoje tradicionalne ekonomske, socialne in kulturološke funkcije. Učinki ekonomske globalizacije in regionalizacije, spremenjene strukture dela in delovnih mest, informacijskih in komunikacijskih tehnologij vplivajo na razpad klasičnega kompaktnega mesta, ki se vedno bolj zliva $z$ obmestnim prostorom $\mathrm{v}$ „urbano regijo“ (Mušič 1998)1. Disperznost urbanih struktur, zlasti na periferiji, potegne za seboj številne negativne vplive na okolje, od zasedanja prostih zelenih površin do ekološkega onesnaževanja zaradi pomanjkljive komunalne opremljenosti. Vse to postavlja pred planerje nove dileme varovanja okolja.

Močan posredni vpliv na okolje predstavlja tudi sprememba pojma lastništva zemljišč. $\mathrm{Ob}$ dejstvu, da je večji del gradbenih aktivnosti danes $v$ rokah zasebnega sektorja, obstaja bojazen, da bodo ekonomski interesi prevladali nad javnimi, zlasti pri skrbi za varstvo okolja. Privatno lastništvo zemljišč in nepremičnin postavlja na-
Planerska orodja Prostorski dokumenti Prostorsko planiranje Varstvo okolja

$V$ besedilu so izpostavljena vprašanja prihodnjega prostorskega planiranja, pri čemer sta kot najpomembnejši izpostavljeni preživetje človeštva in ustvarjanje zdravega in prijetnega okolja. Sledijo jim vprašanja vezana na dileme planiranja za bodočnost in uvajanja novih postopkov ter inštrumentov $v$ planersko prakso.

Environmental protection Planning documents Planning tools Spatial planning

The emphasis in the text is on questions concerning the future of spatial planning, whereby the most important ones are survival of humanity and the creation of healthy and pleasant environments. They are followed by questions on dillemas of planning for the future and the introduction of new procedures and instruments into the planning practice. 
mreč pred planersko stroko popolnoma nove zahteve glede varovanja javnih interesov $v$ prostoru. Zato so za reguliranje trga zemljišč v skladu $\mathrm{z}$ ekonomskimi, sociološkimi in okoljskimi parametri potrebni tudi inštrumenti drugih strok, vključenih v timski način dela (ob prostorskih planerjih zlasti ekonomisti, pravniki in sociologi). Vprašanje, ki se ob tem pojavlja: ali pristojnosti organov oblasti, zlasti javne uprave, $\mathrm{v}$ današnjih razmerah zadoščajo za zaščito javnih interesov, ki predstavlja osnovni smisel njihovega delovanja?

\section{Ali je danes še mogoče govoriti o planiranju $\mathrm{z}$ vidika napovedovanja prihodnosti urbanega razvoja?}

Razvoj v zadnjem desetletju nas prepričuje, da je čas splošno veljavnih in generalno obvezujočih idealov razvoja dokončno minil. Potrebe po globalnem planiranju se umikajo, saj so se možnosti nadzora tega razvoja izkazale za zelo omejene. Bistvo pogojev dela tako ni več definiranje prihodnosti, temveč sposobnost, dopustiti

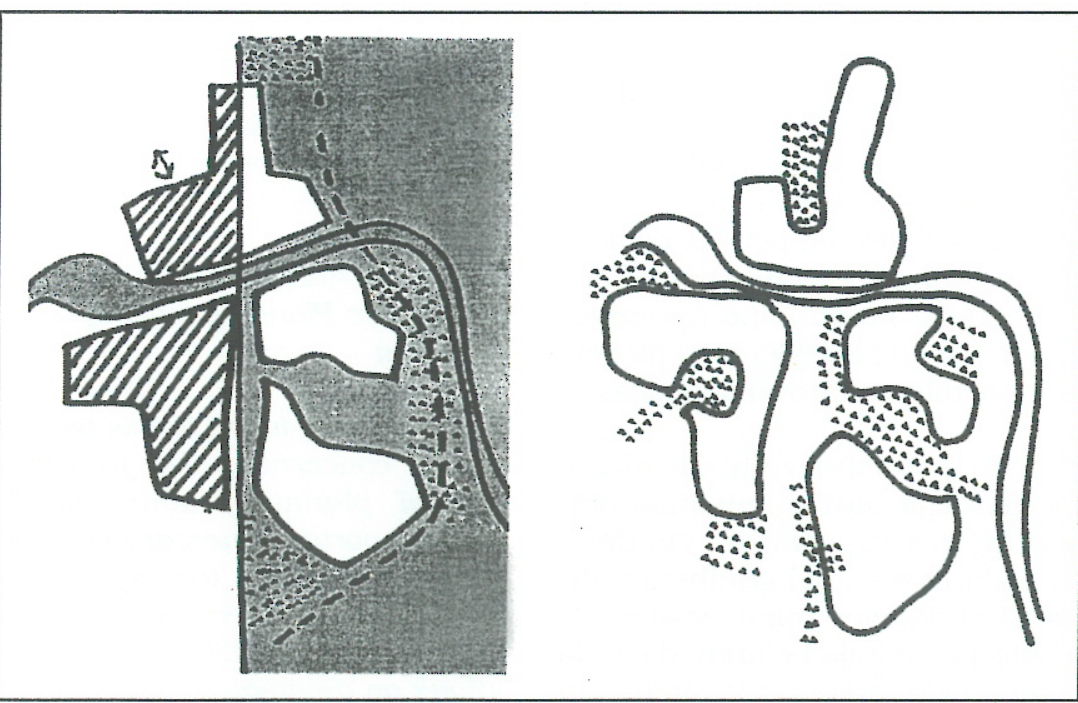

Slika 1: Štiri mesta v enem (vir: Lobnik, Uroš. et al.: Urbanistična zasnova mesta Maribor, osnutek, zvezek 1 - Ustroj mesta, ZUM d.o.o., Maribor, april 1998) dinamične razvojne procese ter jih poskušati usmerjati za prihodnost.2 Planiranje, ki naj bo obravnavano kot proces, mora $\mathrm{v}$ prvi vrsti hitro reagirati na spremembe in temu primerno ukrepati. Prostor se tako zopet obrača $\mathrm{k}$ svojemu bistvu: postaja strateški vir in ne le površina za prostorsko rabo.

Mesta oziroma urbane regije, ki so izpostavljene vedno večji dinamiki najrazličnejših razvojnih procesov, postavljajo pred urbaniste in arhitekte izredno zahtevne naloge, ki nimajo več dosti skupnega s tradicionalnim pojmovanjem stroke. Naraščanje ekološke krize in socialnih konfliktov predstavlja že dodatne izzive. Čas, v katerem je načrtovanje mestnega razvoja služilo v prvi vrsti povečanju urbanih površin za novogradnje, je tako dokončno minil. $Z$ vseh strani se pojavljajo zahteve po vsesplošnem varčevanju $\mathrm{z}$ gospodarskimi resursi, umetnimi in naravnimi (Eberhard, Schumacher 1993, str. 43), kar velja zlasti za zasedanje prostih zelenih površin. Tu je naloga urbanistov in arhitektov bolj ali manj jasna. $Z$ ustreznimi urbanističnimi in arhitekturnimi rešitvami je potrebno znova dokazati - ne le ekološko, temveč tudi ekonomsko - da je dobre pogoje za bivanje možno vzpostaviti tudi znotraj višjih gostot zazidave. $\mathrm{V}$ tem smislu moramo nove razvojne prostore za urbanizacijo iskati in aktivirati predvsem znotraj obstoječe urbanizacije. Najdemo jih zlasti na območjih, ki zahtevajo prestrukturiranje: $\mathrm{v}$ conah $\mathrm{z}$ zastarelo industrijo, železniških terminalih, ki v mestnih središčih ne izkazujejo dovolj intenzivne izkoriščenosti, ipd. Podobno obravnavo zahtevajo neartikulirani mestni robovi in njihova zaledja $\mathrm{z}$ značilno disperzno pozidavo.

\section{Značilnosti novih planerskih pristopov}

Načrtovanje prostora je po svojem izvoru del raznovrstnega družbenega in kulturološkega procesa. Zavedati se moramo, da na ta 
proces lahko sicer do določene mere vplivamo, ne moremo pa ga vnaprej definirati (Rossi 1993, str. 29). V osnovi lahko rečemo, da novim vidikom planiranja tako bolj ustrezajo širša merila celostnega načrtovanja mestnih regij. Načrtovanje parcialnih končnih podob, tradicionalno vezanih na oblikovanje novih struktur, je zamenjalo krmiljenje razvoja mest oziroma urbanih regij. Ta pristop poskuša na različne načine najprej na novo definirati vodilne motive mestnih konceptov, prilagojene aktualnim procesom $\mathrm{v}$ prostoru - od "mesta kratkih poti“, "kompaktnega mesta“, „Vmesnega mesta" (Sievert 1998), do "mrežnega mesta“ (Venturi 1998).

O novih planerskih pristopih lahko govorimo tudi kot o nalogi opazovanja in posredovanja prostorskega dogajanja $\mathrm{v}$ različnih dimenzijah: posredovanja preteklih razvojnih smeri ali njihovih delov $\mathrm{v}$ prihodnost, pretvarjanja abstraktnih političnih in razvojno prostorskih vizij $\mathrm{v}$ prostor in obratno, prizadevanja po uskladitvi in izenačitvi javnih interesov $\mathrm{s}$ tistimi iz privatnega gospodarstva itd. $3 \mathrm{~V}$ praksi narekuje takšen pristop obravnavo razvojnih procesov v posameznih prostorih kot delov večjih strukturnih sistemov. $\mathrm{Za}$ upravljanje teh procesov je torej bistvenega pomena upoštevanje prostora kot celote $\mathrm{v}$ vsej njegovi enovitosti. 4

Čeprav pogosto slišimo misel, da „...mesta ne smemo na novo ustvariti, temveč moramo dopustiti, da se izoblikuje samo..." (Kroll 1998)5, zahtevajo kompleksne razmere določeno prostorsko zgradbo, znotraj katere se lahko izrazijo različne kulture. Predstavljajo grobo ogrodje, ki omogoča strukturiranje prostih površin za različne programe. To $\mathrm{v}$ praksi pomeni potrebo po takšnih mehanizmih, ki omogočajo fazno načrtovanje oziroma neke vrste rastoče modele prostorskih struktur, sposobnih sprotnega prilagajanja danim razmeram (Christiaanse 1994). Za takšne pristope so se uveljavili izrazi, kot so „odprti urbanistični koncepti“ ali "odprto mesto“, ko podrobno določanje rabe in oblikovanja sledi šele $\mathrm{v}$ fazi konkretne realizacijo in ne 5,10 ali 15 let vnaprej. $\mathrm{Za}$ nejasno prihodnost zahtevajo vizije mestnega razvoja tudi določen odprt prostor za vmesne rabe ali rabe za določen čas. Prav zato je možno mestni prostor v okviru globalnih ciljev podrobneje definirati šele $v$ majhnem merilu, kjer je v resnici možno doseči integracijo novih urbanih elementov v obstoječe okolje kot eno osnovnih zahtev trajnostnega planiranja mest.

Takšen pristop je posebno primeren za procese prestrukturiranja posameznih mestnih območij, zlasti tistih z zastarelo industrijo. Poseben problem predstavljajo robovi mest, ki ne premorejo izra-

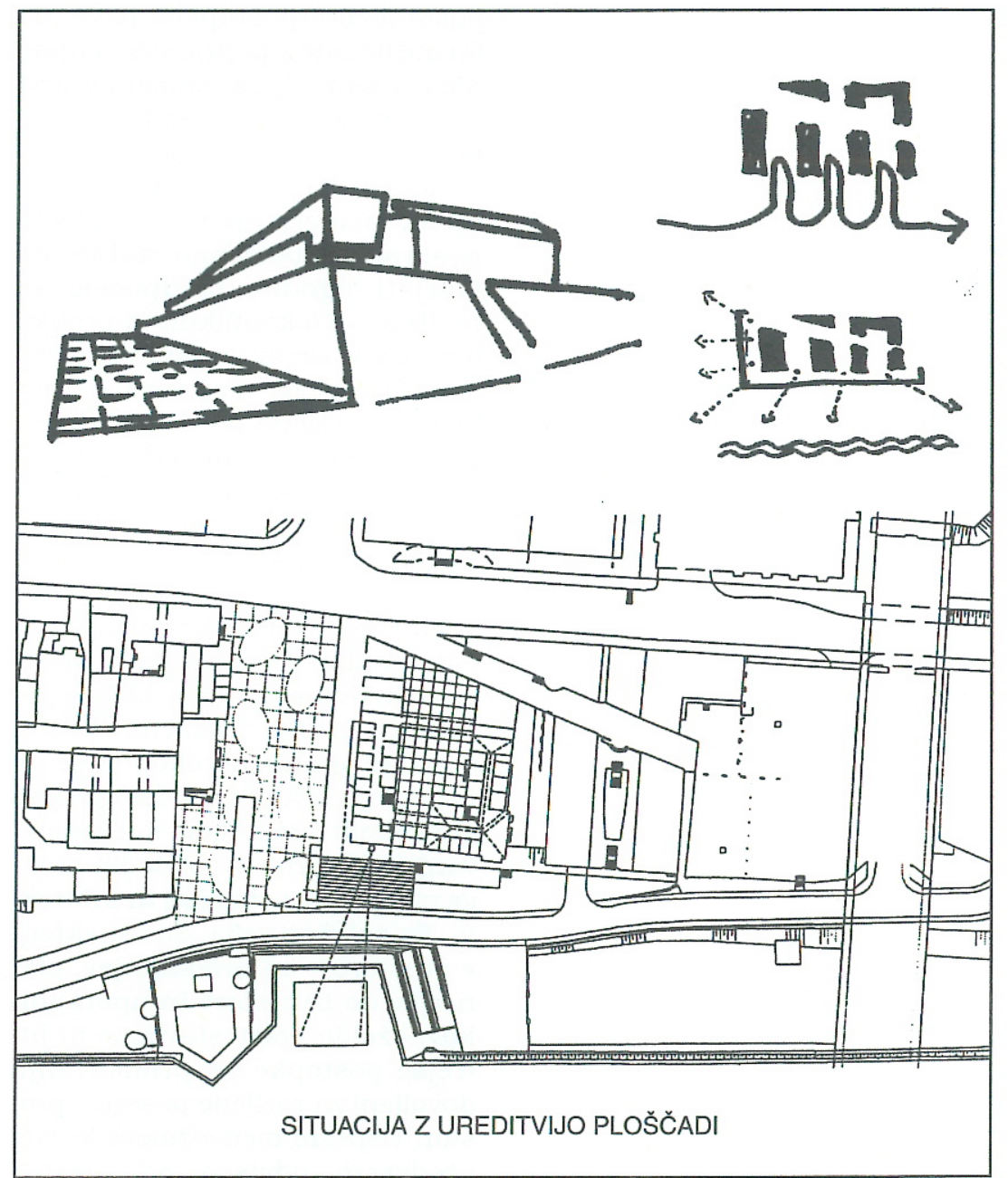

Slika 2: Kompleks zdravstvenega doma v ulici Kneza Koclja, Maribor, izbrana zasnova na vabljenem urbanistično-arhitekturnem natečaju, junij 1998 (avtorja U. Lobnik in A. Podlipnik) 
zitih lastnih prostorsko identifikacijskih danosti. To so kraji, pri katerih je potrebno predvsem upoštevati spremenjene zahteve $\mathrm{v}$ prihodnosti in razviti posebne postopke regionalne prenove. Reflektirajo naj oboje: zgodovinske izkušnje in aktualno preobrazbo, kar v kulturološkem smislu potencialno pomeni moč za nove vizije in njihovo realizacijo. Predstavljajo nove inštitucionalne in vsebinske usmeritve, ki poudarjajo sociološki vidik nove planerske kulture. 6

\section{Dileme planiranja za bodočnost}

Razvojno planiranje prostora pomeni javno delovanje, vezano na politiko, etiko, kulturo. Izhodišče posameznih postopkov je vedno formuliranje političnih ciljev. Slediti tem ciljem, pomeni v prvi vrsti spoznavanje trendov, prognoziranje razvojnih smernic in reagiranje na ugotovitve $z$ vodenjem, usmerjanjem. Za takšne postopke je potrebno stalno ustvarjati ugodne predpogoje za realizacijo, o konfliktih in problemih pa v skrbi za javni interes informirati ter opozarjati strokovno in laično javnost. Govorimo o "mestnem menedžmentu“, ki vključuje tudi procese odločanja o razvoju prostora in njihovi pretvorbi $\mathrm{v}$ prakso.

$\mathrm{V}$ času družbene preobrazbe je čutiti vedno večjo nemoč obstoječega inštrumentarija, ki je izpostavljen kritiki z različnih strani: s strani gradbene ekonomije se pojavljajo zahteve po deregulaciji gradbenih predpisov; kot omejevanje kreativne svobode jih mnoge vidijo tudi urbanisti in arhitekti. Na splošno velja, da vsi akterji $\mathrm{v}$ prostoru - od investitorjev, planerjev do izvajalcev in uporabnikov - želijo poenostavljene in hitrejše postopke pri pridobivanju dovoljenj za različne posege $\mathrm{v}$ prostor. Uspešni menedžment je zato predvsem odvisen od mestne uprave, ki mora delovati kot enotno usmerjen sistem in ne kot zbir različnih storitev. Zlasti je po- membna horizontalna koordinacija med mestno in državno ravnijo odločanja. Poleg jasne politične volje zahteva predvsem ustrezno vodenje, saj tudi v planiranju velja, da uspeh „... ni odvisen samo od vetra, temveč od tega, kako usmerimo jadra..."(Wirth 1993, str. 57).

Velja dodati stališče mnogih strokovnjakov, da ukvarjanje $\mathrm{z}$ novimi gradbenimi predpisi v sedanjih kompleksnih razmerah ni smiselno, ker le-te ne zagotavljajo konsenza za njihovo veljavnost $\mathrm{v}$ praksi. Vsaka regulativa predvideva namreč tudi izjeme, ki dovoljujejo uvajanje novih primernejših inštrumentov. Njihovo uveljavljanje $\mathrm{v}$ praksi zahteva od posameznika visoko strokovno znanje in diplomacijo na vseh ravneh kreiranja in odločanja. V novih razmerah potrebujemo torej kompetentne strokovnjake $z$ osebno odgovornostjo za lastne odločitve. Prav izjeme predstavljajo možnosti za kreativnost in $z$ njo pozitivno klimo za nastanek času primerne mestne kulture. 7

\section{Planerski postopki in inštrumenti v mestmem menedžmentu}

Mestne in občinske regije se neprenehoma spopadajo s tekočimi odločitvami, ki lahko močno vplivajo na razvoj prostora, vendar praviloma niso usmerjene $\mathrm{k}$ natančno določenim ciljem. Mestna politika niha med naklonjenostjo gospodarski sferi v smislu konkurenčne sposobnosti mest in regij ter praviloma temu nasprotnemu prizadevanju za optimiranje bivalnih razmer prebivalcev - volivcev, ki to tudi pričakujejo od svojih legitimno voljenih predstavnikov oblasti. Tem odločitvam se pridružujejo aktivne skupine prebivalcev kot akterji sodobne pluralistične, multikulturne družbe. V imenu demokratične javnosti želijo posredno ali 
neposredno vplivati na razvojne odločitve. Kritični odziv javnosti je tako postal sestavni del planiranja in eden njegovih temeljnih postulatov.

Stari sistemi, ki v veliki meri še veljajo, vključujejo javnost šele v fazi prevere oblikovanih zasnov prostorskega razvoja. Kar danes nujno potrebujemo, je dialog med vsemi udeleženci v začetni fazi planerskega procesa. Ta naj verificira skupne cilje in na osnovi njih izoblikuje ukrepe. Uvajati je treba takšne procese, ki dopuščajo vključevanje najrazličnejših delov demokratične javnosti. Le tako lahko kasneje tudi računamo na pozitivni sprejem javnosti. V tem smislu pridobivajo na pomenu zlasti postopki in inštrumenti sodobnih informacijskih in komunikacijskih tehnik profesionalnega dela $z$ javnostjo.

Naslednja značilnost sodobnih postopkov planiranja je njihova transparentnost. Kompleksnost urbanistične dokumentacije danes je praviloma preobsežna, da bi to dopuščala. Zaradi zakonsko determiniranih časovnih intervalov, v katerih je možna korekcija (praviloma revizije na vsakih 3 do 5 let), postaja načrtovanje prostora vedno bolj neke vrste „naknadno knjigovodstvo" odločitev, ki so bile sprejete $\mathrm{v}$ nekih drugih razmerah. 9 Poseben problem predstavljajo dolgo trajajoči postopki $\mathrm{z}$ različnih zornih kotov, ki ne ustrezajo zahtevam hitrega reagiranja oziroma fleksibilnega prilagajanja na spremembe, obenem pa zahtevajo brezpogojno ohranitev temeljnih vizij mestnega razvoja.

Veliko problemov v postopkih revizije planov se pojavlja zaradi konfliktnosti interesov med lastniki zemljišč in mestno oblastjo (ki v teh postopkih predstavlja javnost!) - zlasti glede spremembe namenske rabe površin. Iskanje konsenza med udeleženimi partnerji zahteva posebne napore za stroko in politiko. Prav participacija kot soudeležba in soodločanje predstavlja nujni inštrument $\mathrm{v}$ planerskih procesih. 10

\section{Uvajanje novih planerskih inštrumentov v prakso}

Skupni cilj vseh aktivnosti prostorskega načrtovanja mora biti izoblikovanje jasnih predstav - vizij o tem, kam in kako se bodo $\mathrm{v}$ izbrani časovni dimenziji določena regija, mesto, kraj razvijali. Razvojni koncepti (plani) naj vključijo smernice, kako sedanje in bodoče probleme obvladati $z$ ekonomskega, regionalnega in okoljskega vidika.

V smislu prostorske dokumentacije razlikujemo:

- dolgoročni vidik, ki ga predstavljajo nadrejene generalne prostorske smernice kot sestavni deli razvojnih konceptov regije, občine,

- srednjeročni vidik, ki ga v okviru občin predstavljajo načrti coniranja,

- kratkoročni vidik - urbanistične študije za raven četrti, središča, soseske itd.

Pojem razvojno planiranje naj $\mathrm{v}$ prvi vrsti upošteva vidike ohranjanja urbane in krajinske enovitosti posameznih regij, mest, naselij ter njim lastne identitete. Zavest o nujnosti tovrstne zaščite, ki po svojem bistvu predstavlja skrb za varstvo okolja, je v novejšem času prisilila občine in regije $\mathrm{k}$ uvajanju nove generacije kombinacije

Primer možnega postopka za izoblikovanje razvojnih ciljev na osnovi dialoga 8

\begin{tabular}{|c|c|}
\hline Analiza stanja in trendov & \multicolumn{1}{c|}{$\begin{array}{c}\text { Obravnava razvojnih ciljev } \\
\text { na osnovi dialoga }\end{array}$} \\
\hline \hline $\begin{array}{l}\text { - analiza obstoječega stanja in možnih } \\
\text { scenarijev } \\
\text { (strokovnjaki različnih strok) }\end{array}$ & $\begin{array}{l}- \text { vključevanje različnih delov urbane } \\
\text { javnosti } \\
\text { (okrogle mize, mestni sveti, v katere so } \\
\text { vključeni laiki, strokovnjaki, politiki) }\end{array}$ \\
\hline
\end{tabular}

Ukrepi, usmerjeni k razvojnim ciljem znotraj trendov prostorskega razvoja

- mrežni delni plani: ekonomsko in socialno planiranje, občinske infrastrukturne politike, urbanistični načrt mesta itd

(strokovnjaki)

POVRATNA INFORMACIJA K URBANI JAVNOSTI 
planov $\mathrm{z}$ načrti razvoja prostora. V prostorskem smislu obsegajo celotno občino ali regijo, za katero določajo glavne razvojne usmeritve, težišča ukrepov in zaščitena območja. V večjih mestih se pojavljajo posamezni načrti za dele teh prostorov, ki so prilagojeni določenemu kraju $z$ upoštevanjem njegove specifike, naravnih značilnosti in krajevne podobe. Oblikovni aspekti razvojnega planiranja izhajajo torej iz konkretnega kraja oziroma lokacije in predstavljajo bistvene kriterije za bodoči razvoj. $\mathrm{Za}$ njihovo realizacijo pa so ob nepopolni regulativi potrebne odločitve, za katerimi stojijo pristojni predstavniki stroke. V formalnem smislu dopolnjujejo srednjeročni vidik planerskih inštrumentov, zato morajo biti formalno-pravno obvezujoči.11

Ko ugotavljamo, da planerske aktivnosti niso več predvsem usmerjene k klasičnemu načrtovanju v praznem prostoru, vidimo, da je centralna tema mestnega planiranja predvsem vprašanje uveljavljanja sprememb v prostoru, zlasti glede namembnosti in izrabe površin. Tovrstne zahteve $v$ majhnem merilu narastejo v večjem merilu v spreminjanja celih mestnih predelov. Eno glavnih ovir predstavlja okostenela kategorizacija planerske dokumentacije. Ta sicer v zadnjem času dopušča preskoke, ki pa ob togosti izhodiščnih dokumentov $\mathrm{v}$ praksi nekako izgubijo na pomenu.

\section{Kakšna so prizadevanja za poenostavitev in reduciranje prostorskih postopkov
in dokumentov?}

V demokratičnih prostorskih razmerah, ki jih najmočneje zaznamuje privatno lastništvo, izhaja osnovna dilema mestne in regionalne prostorske politike iz dvojnosti planerske dokumentacije.
Ta se v principu deli na "plan", obvezujoč za t. i. oblast (občinsko, lokalno), in na "načrt coniranja", ki je obvezujoč za lastnike zemljišč glede namenske rabe in izrabe površin. Največja konfliktnost se pojavlja v časovni dimenziji. Ne samo plan, tudi načrt coniranja je namreč po svojem značaju dolgoročen in praviloma ostaja nespremenjen več let. Lastniku zemljišča predpisuje možnosti in meje učinkovitega ravnanja $z$ lastnim imetjem. Kot inštrument reda ne ureja prostora v celoti, temveč samo enostransko - dvodimenzionalno. Prostor pa je v svojem bistvu enovit, čeprav večplasten, tudi združevalen pojem. Nasprotno je pojem cone po svoji vsebini omejevalen, ločevalen (Zibell 1993: str. 10). Prav dokument coniranja namembnosti površin, $\mathrm{v}$ katerem nekateri $\mathrm{v}$ trendih deregulacije vidijo edini vseobsegajoči dokument, $\mathrm{v}$ iskanju novih oblik planerske kulture zahteva posebej kritično obravnavo.

Plan (razvojni, družbeni itd.) ter načrt coniranja sta torej dva osnovna dokumenta, ki sta $v$ večini evropskih držav za posamezne občine obvezujoča ne glede na njihovo velikost. Čeprav je načrt coniranja morda za manjše občine primeren in učinkovit inštrument urejanja prostora, v večjih občinah zaradi kompleksnosti prostorskih posegov ne zadošča za večje planerske odločitve. Prisotna je potreba po nekakšni vmesni fazi med dvodimenzionalnim definiranjem prostorske rabe in končno fazo urbanističnih načrtov. Kar manjka, so prostorske študije, usklajene s celostnimi razvojnimi koncepti mesta in regije, ki naj določajo grobe okvirje in smernice za konkretne urbanistične in arhitekturne zasnove.

V planerskem smislu lahko govorimo o diametralnem nasprotju med coniranjem kot obliko reaktivnega planiranja in tovrstnimi študijami kot obliko aktivnega planiranja. Načrt coniranja sicer vključuje možnosti korekcije v daljših časovnih presledkih, toda le tridimenzionalna urbanistična študija je sposobna prostorskega 
odziva in prilagajanja trenutnim razmeram. Urbanistična študija kot inštrument "mehkega" urejanja prostora predstavlja neke vrste kombinacijo urbanističnega in arhitekturnega načrtovanja. Prav vključevanje takšnih in podobnih mehanizmov stalnega preverjanja in prilagajanja spremenjenim razmeram manifestira dinamični vidik prostorskega načrtovanja.

Takšne inštrumente poznamo tudi $\mathrm{v}$ domači planerski praksi (smernice, strokovne podlage), kjer pogrešamo njihovo verifikacijo znotraj hierarhije prostorskih dokumentov. Žal se pojavljajo praviloma šele $\mathrm{v}$ fazi neposredno pred konkretno realizacijo, često pod časovnim in ekonomskim pritiskom posameznih investitorjev. Zaradi dolgotrajnosti postopkov prihaja pri njihovi uveljavitvi do nemalo težav. Odločanje v razvojnem procesu je zato zanimivo obravnavati $z$ vidika različnih optik razvojnega planiranja. Pri tem lahko razlikujemo različne dimenzije 12:

\section{Prostorska dimenzija}

Vključuje definiranje ciljnih usmeritev in zagotavlja ohranjanje dolgoročnih in nadrejenih odvisnosti; na omejene konkretne situacije reagira diferencirano $\mathrm{s}$ kratkoročnimi prostorskimi koncepti.

Primeri:

- nadrejena raven generalnih smernic:

kakšen je odnos novonačrtovanega središča do tradicionalnega mestnega središča?

- raven coniranja:

katere namembnosti površin so najbolj iskane?

- podrejena raven:

katere urbanistične in oblikovne podobe so vezane na to namembnost; kakšne zelene površine je možno vključiti?

\section{2. Časouna dimenzija}

Poudarja, da imajo posamezni predeli mesta, regije svojo zgodovino, ki jo moramo ohraniti čitljivo v vsaki planerski fazi. Mesta se praviloma ne spreminjajo skokovito; šele v daljšem časovnem obdobju se iz majhnih delčkov se- stavlja nova slika; nove odločitve se morajo vklopiti $\mathrm{v}$ nadrejene dolgoročne notranje skladnosti v prostoru. Razlikujemo različne procese odločanja:

- linearne planerske procese - vezane na obstoječi tradicionalni planerski inštrumentarij,

- iterativne planerske procese načeloma so dogovor na nove družbene in časovne danosti, saj v vsaki fazi dopuščajo prevero prejšnjih odločitev, vendar niso $\mathrm{v}$ skladu $\mathrm{s}$ pravnimi in planerskimi načeli

- strukturiranje planerskih procesov po sekvencah - omogoča ravnanje v sekvencah, kjer lahko v skladu s potekom določenega števila sekvenc fiksiramo vmesne odločitve.

\section{Družbena dimenzija}

Sicer dopušča iterativne procese odločanja pod pogojem, da ostaja planerski proces v vseh sekvencah transparenten; posreduje rezultate posameznih sekvenc $v$ nadaljnji postopek odločanja, ki je na vpogled vsem zainteresiranim.

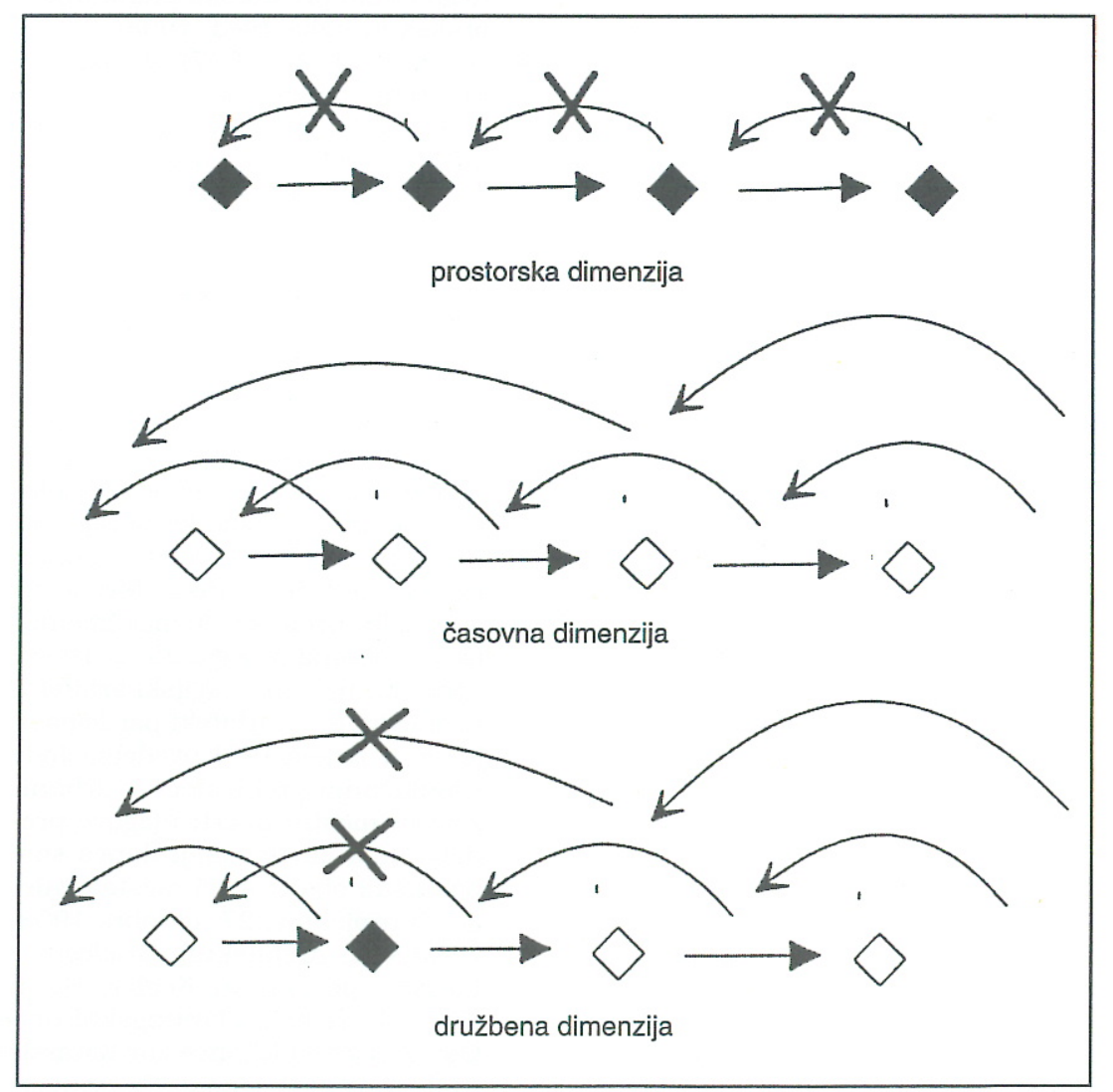

Slika 3: Shematski prikaz dimenzij 
Predpogoj za politike, strokovnjake in prebivalstvo je identifikacija $z$ grajenim in naravnim okoljem. Ko prostorsko načrtovanje zopet postaja javna naloga, je $\mathrm{v}$ smislu odgovornosti stroke do okolja zelo pomembno tudi vključevanje javnosti. Samo tesno prepletanje različnih dimenzij planiranja lahko vzpodbuja kreativno oblikovanje skupnih razvojnih konceptov.

Zaključujem z vprašanjem, ki vsebuje vse tri dimenzije mesta kot sociološkega fenomena sedanjosti: ali smo mi tisti, ki spreminjamo mesto, ali mesto spreminja nas? Britanski arhitekt Richard Rogers odgovarja o novi moči javnega življenja, da „...mesto humanizira in brutalizira; od nas je odvisno, kaj od tega naredimo..."13

Dr. Metka Sitar, univ. dipl. inž. arh., Maribor

\section{Opombe}

1 Mušič, V. B.: v predavanju Sodobne vsebine in metode regionalnega prostorskega planiranja in razvoj poselitve, mednarodna konferenca Regionalno prostorsko planiranje praksa in izzivi, Bled, 1998.

2 Schmidt, J. A. (1997), v razpravi Stadtebaulichen Struktur und Gestaltwandel modellieren (privatni arhiv) dopolnjuje svoja spoznanja za planersko prakso iz dela Stadtebau und evolutiver Struktur- und Gestaltwandel, Verlag Peter Lang GmbH, Frankfurt am Main, 1990.

3 DISP 115 (1993), ETH Zürich, M. Doehler v intervjuju za „Ekspertno anketo v nekdanji Vzhodni Nemčiji“.

4 Da globalizacija ne dopušča razvoja in nadzora sistemov brez napak, temveč zahteva sisteme vodenja, krmiljenja sistemov, ki morajo biti relativno majhni in pod lokalnim nadzorom, trdi Dennis L. Meadows, ameriški profesor menedžmenta; Delo, Sobotna priloga, 28. 2. 1998.

5 Kroll, L., ugledni belgijski arhitekt, imenovan tudi „arhitekt participacije“, ki je že leta 1961 uvedel metode soodločanja prebivalcev v urbanizem in mestni načrt; njegovo predavanje o participaciji danes smo poslušali ob otvoritvi razstave njegovih projektov, 27. oktobra 1998, v Haus der Architektur, Gradec.

6 Povzeto po članku Kegler, H. in Kuhn, R. (1993), Planungskultur Ost: Zwischen Chance zur Katarsis und Abgang eines Reformversuchs, DISP 115, ETH Zürich
7 Rosenmund, Roul (1993), Das Selbstverstandnis der Ordnug, Stadt-Bau-Ordning, ORL-Schriften 44/93, ETH Zürich.

8 Buchmeller, L. et al. (1993), Management der postmodernen Stadt, ORL-Bericht 85/93, ETH Zürich.

9 Koch, M. (1993), Gedanken verloren: Ort(n)ung statt Ordnung, ORL-Bericht 85/93, ETH Zürich.

10 Warmer, H. (1993), So ivel wie nîtig - so wenig wie mîglich, istotam.

11 Zibell, Barbara (1993), Die Ordnung der Unordnung oder: Die Unzugenglichkeit der Planungsinstrumente, ORL-Schriften 44/93, ETH Zürich

12 Povzeto po Tobler, Georg (1993), Neuer Wein in alten Schluuchen Richtplan und Stadtplanung, ORLSchriften 44/93, ETH Zürich.

$13 \mathrm{~V}$ intervjuju za Die Zeit, Hamburg (1998), Mesto pomembnejše od države, Delo, 29.8.1998.

\section{Literatura in viri}

Christiaanse, K.: EUROPAN 3, Dokumente zur Architektur, Heft 2/94

DISP 115, ETH, Zürich 1994.

Koch, M.: Gedanken verloren: Ort(n)ung statt Ordnung, Stadt-BauOrdnung, ORL-Schriften 44/93, ETH, Zürich 1993.

Nussmuller, W., Sitar, M.: The Changing of Housing - The Chance of Solution by Participation. V: Černič Mali, Barbara, Dimitrovska Andrews, Kaliopa, Turner, Bengt: International Conference Housing in Transition, Conference Proceedings, Urbanistični inštitut RS, Ljubljana1998.

Rosenmund, R.: Das Selbstverstundnis der Ordnug, Stadt-Bau-Ordnung, ORLSchriften 44/93, ETH Zurich 1993.

Schmidt, J. A.: Stadtebau und evolutiver Struktur- und Gestaltwandel, Verlag Peter Lang GmbH, Frankfurt am Main 1997.

Sitar, M.: Mîglichkeiten und Grenzen der Steuerung von Zersiedelungsprozessen, dizertacija TU Graz 1998.

Thalgott, C.: Zukunft Stadt - Leitbilder oder nicht? Ohne Leitbild? Staedtebau in Deutschland und Europa, Karl Kraemer Verlag Stuttgart + Zürich 1998

Tobler, G.: Neuer Wein in alten Schluchen - Richtplan und Stadtplanung, ORL-Schriften 44/93, ETH, Zürich 1993.

Warmer, H.: So viel wie nîtig - so wenig wie mîglich, Management der postmodernen Stadt, Orl-Bericht 85/93, ETH, Zürich 1993.

W\#plus: Wohnen und Arbeiten im Informationszeitalter, Zentralvereinigung der Architekten ôstarreichs, Graz 1998.

Zibell, B.: Die Ordnung der Unordnung oder: Die Unzugaenglichkeit der Planungsinstrumente, ORL-Schriften 44/93, ETH, Zürich 1993. 